\title{
Influence of Quality Management Principles on Employees' Performance in First Class Hotels: A research in Alexandria City Hassan Ali Mansour ${ }^{1}$ Wael Mahmoud Aziz ${ }^{2}$ EL Hussein Moawad Said ${ }^{3}$ \\ ${ }^{1}$ High Institute of Tourism and Hotel Management - Alexandria City (EGOTH) \\ ${ }^{2}$ Faculty of Tourism and Hotels, Mansoura University \\ ${ }^{3}$ Faculty of Tourism and Hotels, Fayoum University
}

\begin{abstract}
This article discusses the principles of quality management and benefits of employee's performance and implementation this in Alexandria city. International standard is based on the quality management principles described in ISO 9000.The descriptions include a statement of each principle, in particular to" customer focus, leadership, engagement of people, process approach, improvement, evidence-based decision making, and, relationship management". This paper aims to examine the implementation of quality management principles on employee's performance in first class hotels in Alexandria and specifically in food \& beverage department, the population of study is including 18 first class hotels in Alexandria, to achieve this objective, the researcher surveyed 300 forms to employees who are working in food $\&$ beverage department in the investigated hotels. Therefore it seems advisable for population study to be involved in formal ISO9001-2015 projects in order to improve their overall employee's performance. Data were analyzed using Statistical Package for Social Science (SPSS 23). The results indicated that 46.6 percent of the respondent in hotels are actively involved the quality management principles ISO 9001-2015. A notable proportion of employees in hotels have more than seven years' experience in study population hotels. there are some of challenges and obstacles in these hotels, The most important of these challenges is that these hotels do not have the desire to apply these modern concepts and revert to the routine in the work and the lack of desire to be impulsive and may be due to many of the other challenges that lead to poor performance. Therefore, it seems advisable for hotels to be involved in formal to applying the principles of quality management in order to improve their overall performance.
\end{abstract}

Keywords: Quality Management Principles, ISO 9001-2015, Hotel Industry, Employee's Performance.

\section{Introduction}

The adoption of a quality management systems (QMS) are strategic decision for the hotels industry as they can help to improve overall performance and provide a sound basis for sustainable development initiatives (Tari \& Castejon, 2014). The potential benefits to an organization of implementing a QMS are: the ability to consistently provide products and services that meet customer and applicable statutory and regulatory requirements (Rampersad, 2010). Facilitating opportunities to enhance customer satisfaction (Jackson and Schuller, 2012), Addressing risks and opportunities associated with its context and objectives (Flynn et al., 2014), and the ability to demonstrate conformity to specified quality management system requirements (Jaafreh, 2013), QM is the guidelines for realizing financial and benefits of employee's performance (Talib and Rahman, 2010) .However, the international standard ISO 9001:2015, managing for the sustained success of hotels management , a quality management approach is particularly important for our topic.

Maciariello (2012) refers to consistently meeting requirements and addressing future needs and expectations poses a challenge for organizations in an increasingly dynamic and complex environment. To achieve this objective, the hotels management might 
find it necessary to adopt various forms of improvement in addition to correction and continual improvement, such as breakthrough change, innovation and re-organization. All these international standards are based on eight quality management principles in one way or the other (ISO, 2015). Given that this article addresses the issue of achieving sustainable success of hotels and improvement employee's performance in a wider sense and narrower sense (Pantouvakis and Kafetzopoulos, 2013) we will consider quality management principles (QMP) through the prism of the relevant international standards. Further on, we indicate the standardized description of the principles and benefits arising from their use, as well as measures that the management usually takes in order to improve employee's performances.

\section{Literature Review}

The hospitality industry like all the services sectors, quality management systems is everything. Without principles of the quality that is properly designed, well made and reliable, customers will go elsewhere for the goods and services they require. Hospitality industry strives to produce quality products and services for the guests (customers) in other to ensure repeat purchase (Evangelos et al., 2013).

\section{History of Quality Management}

Quality management in the early 1900s primarily meant inspection and ensure quality product. In the 1930s, statistical analysis style and control of quality were developed by Walter (Tari, 2014). Around the 1950s, some quality Geniuses and gurus made huge contributions to quality management method diffusion. W. Edwards Deming taught quality managing through statistical techniques to Japanese people. Joseph M. Juran introduced the concepts of quality control and managerial breakthrough of organization. Phillip B. Crosby promoted zero defects for quality improvement (Schroeder et al., 2013). From the 1960s quality management has been viewed and imported from a broader perspective as companywide quality control an integrated approach to achieving and sustaining high quality output which involves all levels functions of the organization (Sanchez and Martinez, 2011). From this point of view, quality management is made up by a set an organization quality management practices and techniques (Schroeder et al, 2013) and (Molina et al, 2009) with the purpose to deliver high quality products to customers.

To support and encourage the quality improvement from an international perspective, International Organization for Standardization (ISO) has been established in 1987 including members from 163 countries. The organization provides ISO 9000 as a family of quality management standards and guidelines for organizations to ensure their product and service quality. ISO 9001 (2015) is one of ISO series that focused on seven quality management principles: customer focus, leadership, engagement of people, process approach, improvement, evidence-based decision making, and relationship management, The framework of ISO 9001 (2015) standards follows the PDCA (Plan-Do-Check-Act) (Flynn et al.., 2014).

The PDCA cycle can be briefly described as follows (Tari, 2014):

- Plan: establish the objectives of the system and its processes, and the resources needed to deliver results in accordance with customers' requirements and the organization's policies;

- Do: implement what was planned;

- Check: monitor and (where applicable) measure processes and the resulting products and services against policies, objectives and requirements the results;

- Act: take actions to improve performance, as necessary. 
The use of the specific terminology of this International standard of ISO 9001- 2015 within hotels management, the quality management system (QMS) requirements specified in this International standard are complementary to requirements for products and services and thus aim to improve the performance of enterprises. This International Standard employs the process approach, which incorporates the PlanDo-Check-Act (PDCA) cycle and risk-based thinking. The PDCA cycle enables an organization to ensure that its processes are adequately resourced and managed and opportunity for improvement are determined and acted on (ISO, 2015).

\section{Seven Principles of Quality Management}

This International Standard is based on the quality management principles described in ISO 9000. The descriptions include a statement of seven principles, a rationale of why the seven principles is important for the organization, some examples of benefits associated with the principle and examples of typical actions to improve the organization's performance when applying the principle (Liliane, 2016) ,(ISO, 2015) and (Sanchez and Martinez, 2011).

QMP-ISO 9001:2015 standard meaningfully differ from the previous version, both in the formal and practical terms, it was first issued in 1987: at that time, you had to describe in detail what your business did. What applied in the 1994 version was 'say what you do and do what you say'. In the 2000 version, you had to focus on proper processes in order to continually improve and thereby increase your customer satisfaction. There was nothing added in 2008, but it was more precise about the interpretation of the standard. ISO 9001:2015 was published on September 2015 (ISO, 2015).See (figure 1) illustrates the quality management principles of ISO90012015 standard are constructed around seven QMP the following:

Figure 1: ISO 9001:2015

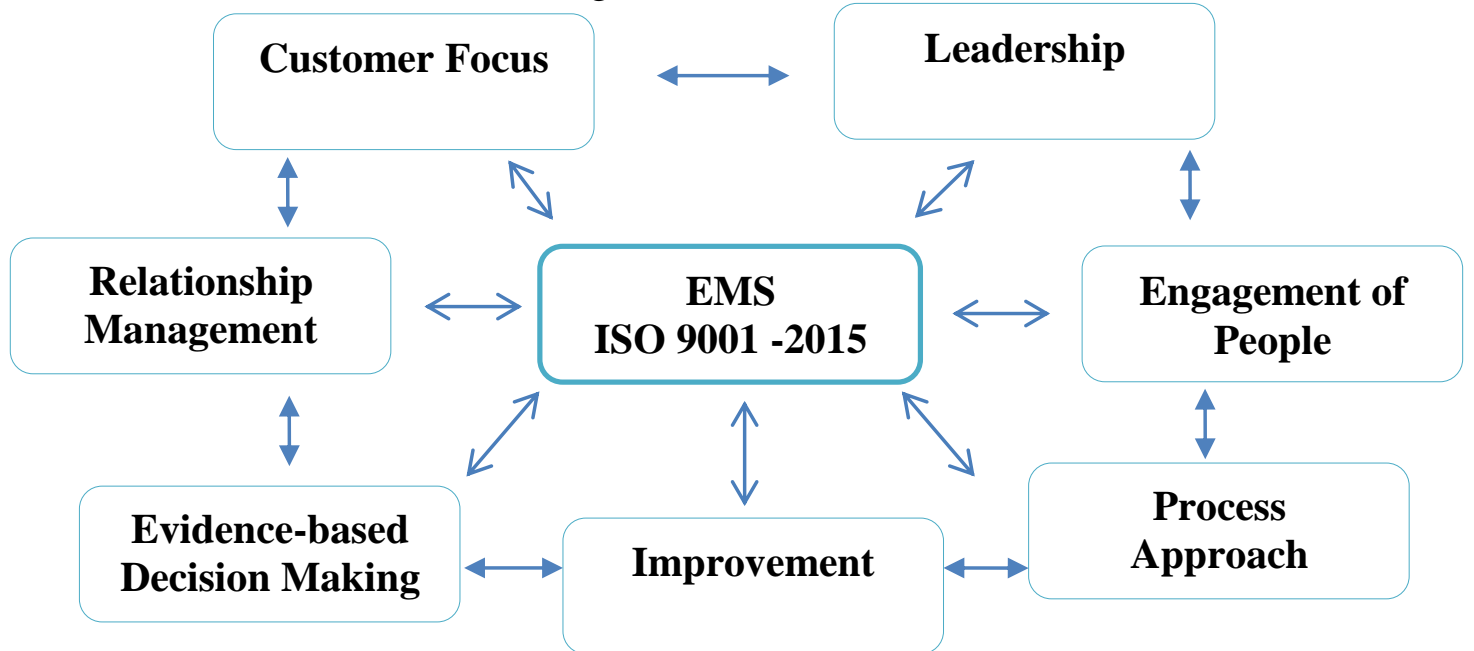

Implementing these ISO 9001 - 2015 principles during your certification process can deliver numerous benefits. Increased employee motivation and productivity, and more efficient use of resources and good performance of employees, continually strengthening your processes will also increase revenues and enable you to build market share by responding rapidly to new opportunities (Crick\& Spencer, 2011). Flynn et al., (2014) add that it is essential that everyone in the company understands their role and feels valued for their contribution to its success. This will not only help you achieve certification but will also demonstrate your organization's commitment to improving quality. 
Expansion of proper methods and tools fosters the development of a tenacious system approach to setting up improving performance. Employee's performance through effective management of resources and implementation of viable processes for the improvement of common perfect and situation in an organization Crick\& Spencer, 2011). While employees performance peter and benefit is the result of organizational improvements in monetary terms and it is realized by applying cost effective management in the organization (ISO, 2015).

\section{Key Benefits (As per ISO 9001:2015)}

$\checkmark$ There is an development in customer value;

$\checkmark$ There is an increase in customer satisfaction;

$\checkmark$ There is an improvement in employees performance;

$\checkmark$ It enhances in repeat works ;

$\checkmark$ It enhances in reputation of the organization;

$\checkmark$ There is an expansion of good performance of organization;

$\checkmark$ There is increase in revenue and market share.

\section{1- Customer focus}

Customer focus is the first QMP and one of the key factors of successful and development performance. The international standard ISO 9001:2008 (ISO, 2009) describes this principle as follows: "Organizations depend on their customers and therefore should understand current and improving performance, should meet customer requirements (Dudu \& Agwu, 2014). This standard identifies three key benefits of this principle: development revenue and Employees performance obtained through flexible, increased effectiveness in the use of the organization's resources to enhance customer satisfaction, as well as improved employee's loyalty leading to repeat business (Crick \& Spencer, 2011).

Flynn et al., (2014) added that sustained success is achieved when an organization attracts and retains the confidence of customers and other interested parties on whom it depends. Every aspect of customer interaction provides an opportunity to create more value for the customer. Understanding current and future needs of customers and other interested parties contributes to sustained success of an organization.

Therefore, any organization must understand current and future customer wanted and should know customer requirements and strive to required customer expectations." The Seven principle definition states "The primary of quality management is to meet customer requirements and to strive to exceed customer expectations ". First and fore the majority of organization must have a clear understanding of who it's direct customer and who are its indirect client (Liliane, 2016).

\section{2- Leadership}

The Eight principles definition stated "heads establishes unity of purpose and direction of the hotel organization (Ahmad \& Yekta, 2012). They must create and maintain the internal environment in which people can become fully involved in achieving the organization's objectives." The 7 principle definition states "Leaders at all levels determine unity of purpose and direction and create conditions in which people are engaged in achieving the quality objectives of the organization. "Leadership is providing role model behaviors consistent with the benefits of the organization. Behavior that will deliver the organizations objectives, internal environment contains the culture and climate, management style, shared, trust, motivation and support. The leadership should consider the needs of all interested 
parties overall customers, owners, employees in organization, suppliers, financier, local communities and society as whole. The leadership should establish a clear vision of the organization's future (Lindebaum \& Cartwright, 2013). The leadership should set a challenging goals and targets. The leadership should originate and sustain a shared values, fairness and ethical role models at all levels of the establishment services. The leadership should Establish trust and eliminate hazards. The leadership should provide people with the required resources training and freedom to act with liability and accountability. The leadership should responsibility, encourage and recognize people contributions (Ahmad \& Yekta, 2012).

The importance of this was also recognized in the standard that details with the sustained success of an organization. In a nutshell, it identifies the most important needs and expectations of interested parties. For example, while the main customer needs and expectations involve product quality, price and deliver performance, the most important needs and expectations of owners/shareholders are profitability and transparency. People in an organization have the need for good working environment and job security, expecting also proper recognition and award for their work. Suppliers and partners focus on mutual benefits and continuity. Society, however, has the need for environmental protection and also expects ethical behavior and compliance with laws and regulations (ISO, 2009).

\section{3- Engagement of People}

It is essential for the organization that all people are competent, empowered and engaged. Competent, empowered and engaged employees throughout the organization enhance its ability to create value. People should be a core efficiency of every organization. Involving people and their abilities at all levels can only benefit your organization, motivating employees, holding accountable for their own performance and involving them in decision making inspire innovation (ISO 9001, 2015).

The international standard ISO 9001:2008 characterized this principle as: "People and employees all levels are the essence of an organization and their full sharing enables their abilities to be used for the organization's benefit". The purpose benefits identified in this quality standard include motivation, obligation and inclusion of people within an institution, and their innovativeness and creativity in the application of its objectives (Rampersad, 2011). Spirited benefits were also identified in the domain of personal responsibility, underlining that people are responsible for their own performance and that ready to participate and give a share in to continual improvements. The standard notes that the application of employees inclusion principle leads to people understanding their role and importance of its support and role in organization and hotels establishment, identifying limitations to their performance, and accepting problems not only as just being their own problems but also taking responsibility for tackling them, valuing their own performance against their personal and general objectives, and to actively strive for increasing own competence, knowledge and experience. In addition to the aforesaid, the standard dealing with sustained success states that the application of this principle shows free exchange of knowledge and experience among people (ISO, 2015).

\section{4- Process Approach}

Fonseca (2015) refer wed to the same standard defined three principle benefits from this, The first one is reflected through reduce costs and shorter cycle time through effective use of resources, the second one through improved, consistent and expected results, and the third one in focused and prioritized improvement performance. 
Application of the process approach principle typically leads to systematically outlining activities necessary to obtain result, and to establishing clear responsibility for managing key activities and their analyzing and measuring. It also leads to identifying the interfaces of this between the functions of the organization and hotels establishment, and focusing on the factors such as resources, methods, and materials that will develop key activities of the organization (Pastor\& Otero, 2016). The application of this principle also leads to evaluating risks, consequences and impacts of activities on customers, suppliers and other interested parties (ISO, 2009).

According to the international standard ISO 9001:2015 (ISO, 2015), the organization shall establish, implement, continue and improve a QMS, including the processes needed and their interactions. The organization has to establish processes necessary for QMS and to apply them in the whole organization and hotels development.

\section{5- Improvement}

Continuously improving your processes and systems improving the organizational overall performance should be a permanent organizational objective (Pastor\& Otero, 2016).Sustained success cannot be recorded without continual improvements. "Organizations can only survive by continual quality improvement". The critical role of personal improvements in establishing sustained success was often pointed: "Whatever an enterprise does internally and externally needs to be improved systematically and continuously: product and service production processes, marketing, service, technology, training and development of people, using information. Let the systemic improvement become your priority (Maciariello, 2012).

\section{6- Evidence-based Decision Making}

Decisions should be based on the analysis of reliable and accurate data and information. Analysis combined with experience and intuition is a powerful decision making tool (Fonseca, 2015).

The international standard ISO 9001:2015 qualified this QMP as follows: "Effective decisions are based on the evaluation of data and information" the benefits of this principle defined by this standard are: informed decisions, an increased ability to establish the effectiveness of past decisions through reference to factual records and increased ability to review, this challenge and change opinions (ISO 9001, 2015). This standard added that application of this principle of factual approach to decision typically leads to ensuring that information are sufficiently accurate, and to making data accessible to those who need them. The application of this principle also leads to "analyzing data using valid methods, and making decisions and taking action based on factual analysis, balanced with experience and intuition” (ISO, 2009).

\section{7- Relationship Management}

For sustained success, organizations manage their relationships with interested parties, such as suppliers (ISO 9001, 2015). Camila \& Mateus (2016) interested that party's influence the performance of an organization and hotels. Success is more likely to be achieved when an organization manages relationships with its interested connection to optimize their impact on its performance. Relationship management with its supplier and partner network is often of particular importance.

In order to achieve sustained success, organizations manage their relationships with interested parties, which affect organization's performances. It is more likely that the sustained success will be achieved when an organization manages relationships with its interested parties so as to optimize their impact on its performance. Management of 
relations with the own network of suppliers and partners is of special importance for organization service, and accordingly to hotels management (Pastor\& Otero, 2016).

\section{Benefits of Implementing Quality System}

To identify the benefits of quality (Schroeder et. al., 2013) considered quality as a critical issue for assuring customer loyalty, competing with other rivals and surviving in difficult market conditions. (Al-Otaibi, 2015) stated that applying high level of quality has several advantages, e.g. less rework, cost cutting, increased productivity, lower prices, and higher market share. (Karapetrovic and Willborn, 2009) added that to achieve and sustain these advantages, continual improvements in quality are important and some of the benefits that a company can gain from a successfullyimplemented quality system (See Table 1)

Table 1: Benefits of Implementing a Successful Quality System
$\checkmark$ Increased confidence in the quality services .
$\checkmark$ Added value, minimized quality cost, maximized revenues .
$\checkmark$ Reduced paper work and bureaucracy .
$\checkmark$ Continuous improvement of the service quality.
$\checkmark$ Attracting new customers.
$\checkmark$ Enhanced hotel image and competitiveness .
$\checkmark$ Improved training of staff, higher morale and job security .
$\checkmark$ More effective cooperation of the client and the hotel .
$\checkmark$ Improved operational control by means of internal and external audits.

\section{Importance of Employees Performance Development}

Generally employee's performance was incorporated for a number of potential agendas. (Hameed \& Waheed, 2011) noted that some of the agendas that lead to E.P procedures being conducted within an organization include:-

1. Improvement in the communication between boss and subordinate through the use of feedback between them.

2. Identification of the scope for performance improvement and the Mean to achieve this.

3. Identification of individual training and development needs.

4. Identification of the potential of individuals for future promotion, succession planning, or for retention or termination purposes.

5. As the basis for remuneration and reward, on the basis of performance.

6. As a powerful means of managerial control, through the setting of objectives in a hierarchical fashion and a review of success or failure in achieving these.

Generally these could be divided in 3 categories according to their importance for the organization, manager or employee:

\section{Benefits for the Organization}

Jackson and Schuller, (2012) outlined four different benefits for the organization. These are targeted training approach based on identified needs, future employee promotion decisions, effective bases for reward decisions and improved retention of employees. The importance of performance appraisal for training and promotion needs is also discussed by (Laurie, 2007). Besides, he identifies an additional benefit: performance appraisal can help to identify inefficient work practices or reveal potential problems, which are restricting the progress of the company. Derven, (2010) 
and Laurie, (2007) suggested that performance appraisal can help the organization to identify the talented employees and future leaders in the company.

\section{Benefits for the Manager}

Modern systems for performance appraisal depersonalize issues. Supervisors focus on behaviors and results, rather than on personalities. Such systems support ongoing communication, feedback and dialogue about organizational goals. Also they support between an employee and a supervisor. Performance appraisal provides a clear target of job standards and priorities and ensures more trust on the relation manager employees (Derven, 2010). Other management benefits of Performance Appraisal are the identification of high performers and poor performers as well as the identification of strengths and development areas (Jackson and Schuller, 2012).

\section{Benefits for the Employee}

Performance appraisal helps to rate the performance of the employees and evaluate their contribution towards the organizational goals. It helps to align the individual performances with the organizational goals and also review employees' performances. Besides, enhancing motivation appraisal is about involvement in the 'big picture' responsibility, encouragement, recognition for effective delivery and effort (Jackson and Schuller, 2012).

\section{Research Method \\ Research Approach}

The aim of this study is to examine the impact of quality management principles application on employee's performance in first class hotels in Alexandria. The research used descriptive analytical approach, to achieve the study goals, the study data is abstracted from different sources like scientific journals, books, internet and data from and questionnaire in food and beverage department employees, This is due because the food and beverage department is largest department is suitable employees, second largest hotels division of revenue after room division department and is important to gives continual impression to guests from hotels. Data collections were analyzed by SPSS "statistical package for the social since" version 23.

\section{Research Design}

Questionnaire design was divided into four main sections, the first one is consists of question about demographic factors of employees in food and beverage department in first class hotels in Alexandria. The second construct: if hotels applied quality management principles. Three construct was used to determine the employee's performance according to Quality management principles and consisted of seven principals. The four construct was the obstacles application of QMS ISO 9001-2015, Five-point likert scale of 1-5 was used (1= Strongly Agree, 5= Strongly Not Agree).

\section{Population and Sample}

The target population for this study was the employees in food and beverage department in first class hotels sector in Alexandria which consist of 18 hotels according to Egyptian Hotels Association (2015); and the number of employees working in it's about 1343 employees according to (human resource management in hotels), this study is based on a sample of employees in four and five star hotels in Alexandria the number of 370 forms; which was selected randomly. Finally, these results only 300 usable questionnaires were collected comprising the final sample of 
the study which comprised of 81 percent of the total number of questionnaires distributed. According to Kwortnik (2008) a minimum sample size of twelve is suitable for qualitative research projects for which the main goal is to get deeper understanding of a phenomenon; this research estimated the sample of percentage (28 $\%)$ as sufficient to meet this criterion. This response rate can be considered satisfactory for this kind of survey. Cronbach's alpha was used to assess survey reliability. The reliability coefficient was 0.812 , which is considered as acceptable reliability.

\section{Hypotheses of the Study}

- There is significant relationship between application of quality management principles and improving employee's performance.

- There is significant relationship between barriers and challenge of application quality management systems to employee's performance.

\section{Results and Discussions}

\section{Personal Information Analysis (Demographic Factors)}

The following table (2) shows the personal Information of questionnaire in population study in hotels as follows:

Table 2: General Profiles of the Surveyed Hotels

\begin{tabular}{|l|c|c|l|c|c|}
\hline \multirow{2}{*}{ Attribute } & \multicolumn{2}{|c|}{$\mathrm{N}=300$} & Attribute & \multicolumn{2}{c|}{$\mathrm{N}=300$} \\
\cline { 2 - 3 } & $\mathrm{N}$ & $\%$ & & $\mathrm{~N}$ & $\%$ \\
\hline Gender : & & & Experience : & 20 & 7 \\
Male & 230 & 77 & Less than 3 years & 50 & 17 \\
Female & 70 & 23 & $3<7$ & 190 & 63 \\
\hline Age : & & & $7<12$ & 40 & 13 \\
$21<30$ & 20 & 7 & More Than 12 & & \\
$30<40$ & 120 & 40 & Classification : & 160 & 53 \\
$40<50$ & 130 & 43 & 4 Stars & 140 & 47 \\
More than 50 & 30 & 10 & 5 Stars & 190 & 63 \\
\hline Function: & & & Ownership : & 50 & 17 \\
Management & 130 & 43 & International Chain & 60 & 20 \\
Supervisor & 170 & 57 & Local Chain & & \\
& & & Private Sector & & \\
Education : & 3 & 1 & & & \\
High School & 17 & 6 & & & \\
Education Diploma & 230 & 77 & & & \\
University Education & 50 & 16 & & & \\
Postgraduate & &
\end{tabular}

Table (2) showed that the table above shows the demographic factors of the employee's hotels and this as follows:

- Gender: It was found the majority of the study population in questionnaire is male $77 \%$, while the female percentage is $23 \%$. Therefore, Males continue to bear a heavier burden when it comes to balancing work and more than females to have strong control over working conditions and bear the burdens of the position of director, which is preferred by hotels to put males in leadership positions more than females, and this is shown by previous data.

- Age : It turns out that about the age the most of population study is 30 to 50 years with percentage $84 \%$, because the most of Director you'll need experience owners in work, and the next age is more than 50 years, finally 21 to 30 was percentage $7 \%$. 
- Function: the majority of the study population showed that is headed towards the selection (Supervisor) where it came percentage 57\%, and (Managers) came with $43 \%$. This is very logical because this questionnaire to be answered by managers in the role of hotel manager you would be responsible for the day-to-day management of a hotel and its staff. You would have commercial accountability for budgeting and financial management, planning, organizing and directing all hotel services.

- Education: the majority of the study population was chosen as a (University Education) with percentage $77 \%$. This is because the position of directors must have university education, since it is unreasonable to have the position of director and not have university education.

- Experience: the years of experience in the field of work, it was found that the majority of the population study is headed towards choice ( 7 to 12 years) came percentage $63 \%$, because access to the position of director must have years of good experience in the field of work to be Capable of bearing the burden of work and familiar with all aspects and positions that managers may face.

- Classification: According to the data in managers questionnaire about hotels classification the data will come 4 stars hotels was percentage 53\%, and five stars hotels it come $47 \%$.

- Ownership of Hotels: According to the data was found about ownership of hotels about the population study, (international chain) is the largest percentage is was 63\%, the private sectors hotels will the second stations with percentage $20 \%$, and finally local chain hotels will come $17 \%$ percentage.

\section{Application of Quality Management Principles ISO-9001-2015 in Hotels}

According to this question the application of quality management principles in population study hotels, into 2 main categories, this is illustrated by the following Table (3):

Table 3: Responsible Unit about QMS

\begin{tabular}{|r|r|c|c|c|c|}
\hline & & Frequency & Valid Percent & Mean & Std. Deviation \\
\hline \multirow{2}{*}{ Valid } & Yes & 140 & 46.6 & & \\
\cline { 2 - 6 } & No & 160 & 53.3 & 1.56 & 0.50 \\
\hline \multicolumn{2}{r}{ Total } & 300 & 100.0 & & \\
\hline
\end{tabular}

In terms of the opinion of the managers, and the data in table (3), is there an independent unit is responsible for managing the quality management systems in hotel. The results showed that more than half of the investigated hotels did have specialized unit for managing quality management $(53.3 \%)$, while $46.7 \%$ of the hotels that had unit responsible for managing quality ,the arithmetic mean with did not approval is 1.56 , the standard deviation is 0.50 less than half of the central.

\section{If the Results is yes About (Responsible about QMS-ISO9001-2015)?}

The previous table showed that the total number of employees responding to this questionnaire represent (140) Questionnaire form, the rate of $46.6 \%$ of the total number (300) employees in population study in four and five star hotels in Alexandria, which is the whole community of the study and their answers are explained as follows: 
International Journal of Heritage, Tourism and Hospitality Vol. (12), No. (2/2), September, 2018 By: Faculty of Tourism and Hotels, Fayoum University, Egypt

Table 4: Results of respondents' views regarding QMS (ISO 9001-2015) application

\begin{tabular}{|c|c|c|c|c|c|c|c|c|c|c|c|c|c|c|}
\hline $\begin{array}{l}\mathrm{N} \\
\mathrm{O}\end{array}$ & " General Question " & \multicolumn{2}{|c|}{$\begin{array}{c}\text { Strongly } \\
\text { Agree }\end{array}$} & \multicolumn{2}{|c|}{ Agree } & \multicolumn{2}{|c|}{ Neutral } & \multicolumn{2}{|c|}{ Not Agree } & Mean & Std.D & C.V & $\mid \begin{array}{l}A \\
Z\end{array}$ & $\begin{array}{l}\text { Sig } \\
* *\end{array}$ \\
\hline \multirow[t]{3}{*}{1} & \multicolumn{14}{|l|}{ Customer Focus } \\
\hline & $\begin{array}{l}\text { QMS application is } \\
\text { achieve the wishes and } \\
\text { Desires of customers. }\end{array}$ & 70 & $\begin{array}{l}50 \\
\%\end{array}$ & 60 & $\begin{array}{l}42 . \\
9 \%\end{array}$ & 10 & $\begin{array}{c}7.1 \\
\%\end{array}$ & - & - & 1.57 & .64 & 40.76 & 6 & .000 \\
\hline & $\begin{array}{l}\text { Hotel management will } \\
\text { monitor the level } \\
\text { service provided to } \\
\text { customer's satisfaction. }\end{array}$ & 40 & $\begin{array}{l}28 . \\
6 \%\end{array}$ & 90 & $\begin{array}{l}64 . \\
3 \%\end{array}$ & 10 & $\begin{array}{c}7.1 \\
\%\end{array}$ & - & - & 1.78 & .57 & 32.02 & 3 & .000 \\
\hline 2 & \multicolumn{14}{|l|}{ Leadership } \\
\hline & $\begin{array}{l}\text { Hotel management has } \\
\text { taken sufficient care to } \\
\text { the QMS to doing his } \\
\text { job perfectly. }\end{array}$ & 60 & $\begin{array}{l}42 . \\
9 \%\end{array}$ & 60 & $\begin{array}{l}42 . \\
9 \%\end{array}$ & 20 & $\begin{array}{l}14 . \\
3 \%\end{array}$ & - & - & 1.71 & .72 & 42.10 & 9 & .000 \\
\hline & $\begin{array}{l}\text { The quality } \\
\text { management system is } \\
\text { applied on a scientific } \\
\text { and systematic basis. }\end{array}$ & 70 & $\begin{array}{l}50 \\
\%\end{array}$ & 60 & $\begin{array}{l}42 . \\
9 \%\end{array}$ & 10 & $\begin{array}{c}7.1 \\
\%\end{array}$ & - & - & 1.57 & .64 & 40.76 & 6 & .000 \\
\hline 3 & \multicolumn{14}{|l|}{ Engagement of People } \\
\hline & $\begin{array}{l}\text { Selection and } \\
\text { recruitment of staff is } \\
\text { according to the } \\
\text { specific objectives to } \\
\text { the QMU in hotel. }\end{array}$ & 40 & $\begin{array}{l}28 . \\
6 \%\end{array}$ & 50 & $\begin{array}{l}35 . \\
7 \%\end{array}$ & 50 & $\begin{array}{l}35 . \\
7 \%\end{array}$ & - & - & 2.07 & .82 & 39.61 & 10 & .000 \\
\hline & $\begin{array}{l}\text { Training on QMS has a } \\
\text { positive and effective } \\
\text { impact on the } \\
\text { employee's } \\
\text { performance. }\end{array}$ & 20 & $\begin{array}{l}14 . \\
3 \%\end{array}$ & 80 & $\begin{array}{l}57 . \\
1 \%\end{array}$ & 10 & $\begin{array}{c}7.1 \\
\%\end{array}$ & 30 & $21.4 \%$ & 2.35 & 1.00 & 42.55 & 12 & .000 \\
\hline 4 & \multicolumn{14}{|l|}{ Process Approach } \\
\hline & $\begin{array}{l}\text { The implementation of } \\
\text { QMS achieves the } \\
\text { objectives and } \\
\text { strategies of the hotel. }\end{array}$ & 20 & $\begin{array}{l}14 . \\
3 \%\end{array}$ & 90 & $\begin{array}{l}64 . \\
3 \%\end{array}$ & 30 & $\begin{array}{l}21 . \\
4 \%\end{array}$ & - & - & 2.07 & .61 & 29.46 & 4 & .000 \\
\hline & $\begin{array}{l}\text { Recommendations of } \\
\text { QMS are detection } \\
\text { errors development } \\
\text { correction procedures. }\end{array}$ & 50 & $\begin{array}{l}35 . \\
7 \%\end{array}$ & 90 & $\begin{array}{l}64 . \\
3 \%\end{array}$ & - & - & - & - & 1.64 & .49 & 29.87 & 1 & .000 \\
\hline 5 & \multicolumn{14}{|l|}{ Improvement } \\
\hline & $\begin{array}{l}\text { Level of service } \\
\text { Success and EP } \\
\text { improvement is due } \\
\text { mainly to role of QMS } \\
\text { in hotel. }\end{array}$ & 80 & $\begin{array}{l}57 . \\
1 \%\end{array}$ & 30 & $\begin{array}{l}21 . \\
4 \%\end{array}$ & 30 & $\begin{array}{l}21 . \\
4 \%\end{array}$ & - & - & 1.64 & .84 & 29.26 & 11 & .000 \\
\hline & $\begin{array}{l}\text { There is a strong } \\
\text { impact on the } \\
\text { implementation of the } \\
\text { QMS to improve EP in } \\
\text { F\&B department }\end{array}$ & 60 & $\begin{array}{l}42 . \\
9 \%\end{array}$ & 70 & $\begin{array}{l}50 \\
\%\end{array}$ & 10 & $\begin{array}{c}7.1 \\
\%\end{array}$ & - & - & 1.64 & .63 & 38.41 & 5 & .000 \\
\hline 6 & \multicolumn{14}{|c|}{ Evidence -Based Decision Making } \\
\hline & $\begin{array}{l}\text { The evaluation of EP is } \\
\text { according to clears } \\
\text { standard Developed by } \\
\text { QMU. }\end{array}$ & 20 & $\begin{array}{l}14 . \\
3 \%\end{array}$ & 100 & $\begin{array}{l}71 . \\
4 \%\end{array}$ & 20 & $\begin{array}{l}14 . \\
3 \%\end{array}$ & - & - & 2.00 & .55 & 27.50 & 2 & .000 \\
\hline & 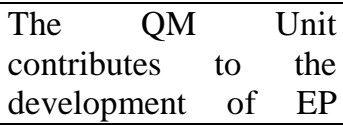 & 20 & $\begin{array}{l}14 . \\
3 \%\end{array}$ & 50 & $\begin{array}{l}35 . \\
7 \%\end{array}$ & 30 & $\begin{array}{l}21 . \\
4 \%\end{array}$ & 40 & $28.6 \%$ & 2.64 & 1.08 & 40.90 & 14 & .000 \\
\hline
\end{tabular}


International Journal of Heritage, Tourism and Hospitality Vol. (12), No. (2/2), September, 2018

By: Faculty of Tourism and Hotels, Fayoum University, Egypt

\begin{tabular}{|c|c|c|c|c|c|c|c|c|c|c|c|c|c|c|}
\hline & $\begin{array}{l}\text { according to the global } \\
\text { trend of SQ. }\end{array}$ & & & & & & & & & & & & & \\
\hline \multirow[t]{2}{*}{7} & \multicolumn{14}{|l|}{ Relationship Management } \\
\hline & $\begin{array}{l}\text { Hotel management is } \\
\text { interested to building } \\
\text { good relations with } \\
\text { others do with them. }\end{array}$ & 20 & $\begin{array}{l}14 . \\
3 \%\end{array}$ & 80 & $\begin{array}{l}57 . \\
1 \%\end{array}$ & 10 & $\begin{array}{l}7.1 \\
\%\end{array}$ & 30 & $21.4 \%$ & 2.35 & 1.00 & 42.55 & 12 & .000 \\
\hline & $\begin{array}{l}\text { The objective of the } \\
\text { hotel is to obtain a } \\
\text { global certificate for } \\
\text { the QMS such as ISO. }\end{array}$ & 90 & $\begin{array}{l}69 . \\
2 \%\end{array}$ & 30 & $\begin{array}{l}23 . \\
1 \%\end{array}$ & 10 & $\begin{array}{c}7.7 \\
\%\end{array}$ & _- & | & 1.38 & .65 & 47.10 & 8 & .000 \\
\hline \multicolumn{10}{|c|}{ Total } & 26.41 & 10.24 & 504.8 & & .000 \\
\hline \multicolumn{10}{|c|}{ Total Mean } & 1.88 & 0.73 & & & \\
\hline
\end{tabular}

The values as shown from the results in the previous table (4) regarding the questionnaire forms responses about the hotels is applied to quality management system ISO 9001-2015 that the total mean (1.88) and the standard deviation is $(0.73)$

\section{1- Customer Focus:}

According to the data in table (4) the majority of the study population were (Agree, Strongly Agree) on implementer QMS chivies the customers satisfaction this agree with percentage $92.9 \%$ and the arithmetic mean was 1.57 and a standard deviation is 0.64 , the results is consist with (Mensah, 2009) that the application of quality system is achieve goals and reach customer satisfaction, quality is a process that takes precedence to offers high service quality to the guests.

Second questions: Hotel Management will monitor the level service provided to customer's satisfaction, the majority of the study population is (Agree and Strongly Agree) There is a strong effect of applying quality systems to improve the performance of employees inside the hotel and This is agree with (Deming ,2008) he pointed that quality has a strong influence in improving the performance of employees and it gives a good advantage in organizing work and improving performance in a scientific and coordinated manner

\section{2- Leadership}

The data in the previous table (4) indicate that the majority of the population of the study is (Agree and Strongly Agree) on hotel management has taken sufficient care to the QMU to doing his Job perfectly with percentage $85.8 \%$ and the arithmetic mean is 1.71 and the standard deviation is 0.72 According that the data received indicate a strong statistical significance, This result is consistent with Nischithaa and Narasimha (2014) where they emphasized the importance of The unit is responsible for the quality management in hotel and training of quality is improves performance and adapts to the hotel's objectives.

Second questions: The respondents were asked quality management system is applied on a scientific and systematic basis, the most of the respondents their results were (Agree and Strongly Agree) with percentage is $92.9 \%$ of the total sample, with the Arithmetic mean average of 1.57 and a standard deviation of 0.64 and a Strong morale level. This result is consistent with Wellens, (2008) that quality management is a process to ensure that all activities and business must be carried out efficiently to achieve the objectives of organization through quality and must be scientific and systematic basis. 


\section{3- Engagement of people}

According to the clear from previous results in table (4) show that the most of the populations study are headed to the answer (Agree and Strongly Agree) and were $64.3 \%$. The Arithmetic mean was 2.07 , we find that the majority of the sample of the study is the recruitment and recruitment of staff according to the objectives set for quality, but from the point of view of the researcher that the quality management unit has a secondary role in the selection and employment of workers and not a key role because the main role rests with the Human Resources Unit and the training unit in the hotel This is confirmed by Dennis ,2012) that the process of recruitment and recruitment of employees is a very complex process and must be characterized by the laws and regulations determined by the department of human resources to meet the purpose of each job.

Second questions: The results showed that the most of the managers in the population study were (Agree and Strongly Agree) on training on quality management systems they were down $71.4 \%$ with Arithmetic mean average of 2.35 and a standard deviation of 1.00. There is a strong moral significance. The results are consisted with Lin (2010) that agree with (Nischithaa and Narasimha, 2014) where they stressed the importance of employees, training programs for the employees are working to improve the performance and develop according to the objectives of the hotel, which makes employees feel satisfaction and enhance their moral spirit.

\section{4- Process Approach}

As for the previous question, showed that in table (4) the majority of the study population headed towards (Agree and Strongly Agree) on Implementation of quality management systems achieves the objectives and strategies in hotel, with an approval rate percentage is $78.6 \%$ and Arithmetic mean average of 2.07. And the standard deviation is 0.61 ; it also highlights the importance of having a unit responsible for managing the quality systems inside the hotel because it helps achieve realistic goals that can be implemented. The quality management unit contributes to the achievement of these objectives. And this Agreed with (Mensah, 2009) that the application of quality systems helps achieve goals and reach customer satisfaction and quality is a process that takes precedence to offer high quality tourism services.

Second questions: The data in the previous table (4) indicate that the majority of the population study items oriented $(100 \%)$ towards the choice of (Agree and Strongly Agree) with a mean of 1.64 and a deviation of 0.49 points less than half of the Arithmetic mean, commenting on the data received, we find that the majority of the population study work on the recommendations of the quality management unit and the creation of errors and work on the prevention of these errors, this is consistent with $\mathrm{Yu}$ (2008) confirmed that the quality management unit has a significant impact on the organizational performance within the organizations and lead to improvement overall performance within organization.

\section{5- Improvement}

In view of the answers given in the previous question, we find that the majority of the sample study tends to be chosen (Agree and Strongly Agree) on Success of Service and employee's performance improvement is According to Role of quality management unit by a percentage $78.6 \%$ and the mean of 1.64 was the standard deviation 0.84 , we find the quality management unit is importance in hotels facilities and this is and managers hotels is must be care about this, This is consistent with (Hayes and Ninemeier ,2006) so there is six elements to success of the quality 
management within the hotel and this was confirmed by drawing Table (4), while a ratio of $21.4 \%$ were your answers is (neutral) and it can be because of this that there are limitations to some extent in the performance of the quality management. It needs more effort and development inside the hotel.

Second questions: With regarded to the results presented in the previous table (4), we find that the majority of the population study is headed towards selection (Agree and strongly agree) on Strong Impact on Implementation quality management systems to Improve Employees Performance in F\&B Department, Where the percentage of $92.9 \%$ with a mean of 1.64 and the standard deviation of 0.63 less than half the center, This refer to Deming (2008) pointed out that quality has a strong influence in improving the employees performance and it gives a good advantage in organizing work and improving performance in a scientific and coordinated manner.

\section{6- Evidence -Based Decision Making}

Based on the data in table (4) it is clear that the majority of the population study tends to be positive (Agree and Strongly Agree) about evaluation of employees performance is there according to clears standard developed by quality management unit, with percentage $85.7 \%$ And the mean is 2.00 and the standard deviation 0.55 , we find that the majority of study population depends on the quality management unit in the development of procedures and structure of departments and follow-up and implementation of senior management plans and control, and these results agree with (Wellens, 2008) Quality management is a process to ensure that all the activities required to develop and provide product and service to customers efficiently and efficiently.

Second questions: It is clear from the previous question in table (4) that the most of the population study results in positive responses (Strongly Agree and Agree) bout quality management unit contributes to development of employee's performance according to the global trend of service quality with percentage $(50 \%)$, The mean is 2.64 and the standard deviation is (1.08) we find that the most of results about population of the study is positive responding this may be due Their faith the importance of quality management units in hotels, results is consist with (Tatiana, 2007) Quality Management In order to establish a product and service according to international standards to meet the needs of customers and stressed that this should be between 3: $4 \%$ of budget hotels.

\section{7- Relationship Management}

The results showed that the most of the managers in the population study were (Agree and Strongly Agree) on hotel management is interested to building good relations with others do with them, they were percentage is $71.4 \%$ with Arithmetic mean average of 2.35 and a standard deviation of 1.00. There is a strong moral significance. This was confirmed by (jakson and Schuller, 2012) he refers that to succeed in this career, you need to become a good communicator and to actively seek information about what's going on in the hotel.

Second questions: The data in the previous table (4) indicate that the majority of the population study is oriented towards the choice were (Agree and Strongly Agree), about objective of the hotel is to obtain a global certificate for the quality management systems such as ISO, with percentage is $92.7 \%$.We find that the majority of the population study aims to obtain a certificate about quality, which was confirmed by (Wilcow, 2009) he add the quality needs to demonstrate its ability to consistently provide product that meets customer and applicable statutory and regulatory 
requirements, and aims to enhance customer satisfaction through the effective application of the system.

If the Results is No about (Responsible QMS ISO 9001-2015)?

The previous table showed that the total number of employees responding to this questionnaire represent (160) Questionnaire form which is the whole community of the study and their answers are explained as follows:

Table 5: Obstacles of the QMS application in the investigated Hotels

\begin{tabular}{|c|c|c|c|c|c|c|c|c|c|c|c|c|c|c|c|c|}
\hline $\begin{array}{l}\mathrm{N} \\
\mathrm{o}\end{array}$ & " General Question " & \multicolumn{2}{|c|}{$\begin{array}{l}\text { Strongly } \\
\text { Agree }\end{array}$} & \multicolumn{2}{|c|}{ Agree } & \multicolumn{2}{|c|}{ Neutral } & \multicolumn{2}{|c|}{ Not Agree } & \multicolumn{2}{|c|}{$\begin{array}{l}\text { Strongly } \\
\text { Not } \\
\text { Agree }\end{array}$} & \multirow{2}{*}{\begin{tabular}{|} 
Mean \\
2.94
\end{tabular}} & \multirow{2}{*}{$\begin{array}{c}\begin{array}{c}\text { Std. } \\
\text { D }\end{array} \\
1.41\end{array}$} & \multirow{2}{*}{$\begin{array}{l}\text { C.V } \\
54.76\end{array}$} & \multirow{2}{*}{$\frac{\mid \mathrm{A}}{9}$} & \multirow{2}{*}{$\begin{array}{l}\text { Sig } \\
* * \\
.000\end{array}$} \\
\hline 1 & $\begin{array}{l}\text { Boring Routine, Holding } \\
\text { Style Administrative Present } \\
\text { and Refusal the Change. }\end{array}$ & 4 & $25 \%$ & 5 & $\begin{array}{c}31.2 \\
\%\end{array}$ & 1 & $6.2 \%$ & 3 & $\begin{array}{c}18.8 \\
\%\end{array}$ & 3 & $\begin{array}{c}18 . \\
8 \\
\%\end{array}$ & & & & & \\
\hline 2 & $\begin{array}{l}\text { Lack of } \quad \begin{array}{r}\text { employee's } \\
\text { participation } \\
\text { makers. }\end{array} \text { to decision } \\
\end{array}$ & 3 & $\begin{array}{c}18.8 \\
\%\end{array}$ & 7 & $\begin{array}{c}43.8 \\
\%\end{array}$ & 3 & $\begin{array}{c}18.8 \\
\%\end{array}$ & 3 & $\begin{array}{c}18.8 \\
\%\end{array}$ & - & - & 2.38 & 1.02 & 42.85 & 7 & .000 \\
\hline 3 & $\begin{array}{l}\text { Making up arguments for } \\
\text { not applying quality } \\
\text { concepts. }\end{array}$ & $\begin{array}{l}- \\
-\end{array}$ & - & 6 & $\begin{array}{c}37.5 \\
\%\end{array}$ & 3 & $\begin{array}{c}18.8 \\
\%\end{array}$ & 6 & $\begin{array}{c}37.5 \\
\%\end{array}$ & 1 & $\begin{array}{c}6.2 \\
\%\end{array}$ & 3.12 & 1.02 & 32.69 & 6 & .000 \\
\hline 4 & $\begin{array}{l}\text { Lack of training programs } \\
\text { specialized to } \\
\text { management applications. }\end{array}$ & 3 & $\begin{array}{c}18.8 \\
\%\end{array}$ & 6 & $\begin{array}{c}37.5 \\
\%\end{array}$ & 5 & $\begin{array}{c}31.2 \\
\%\end{array}$ & 2 & $\begin{array}{c}12.5 \\
\%\end{array}$ & - & - & 2.37 & .96 & 40.50 & 5 & .000 \\
\hline 5 & $\begin{array}{l}\text { No need to apply the quality } \\
\text { system because it is an } \\
\text { additional burden in hotels. }\end{array}$ & 2 & $\begin{array}{c}12.5 \\
\%\end{array}$ & 7 & $\begin{array}{c}43.8 \\
\%\end{array}$ & 6 & $\begin{array}{c}37.5 \\
\%\end{array}$ & 1 & $6.2 \%$ & - & - & 2.37 & .81 & 34.17 & 1 & .000 \\
\hline 6 & $\begin{array}{l}\text { Not sure to application } \\
\text { quality system as required. }\end{array}$ & 1 & $6.2 \%$ & 3 & $\begin{array}{c}18.8 \\
\%\end{array}$ & 6 & $\begin{array}{c}37.5 \\
\%\end{array}$ & 6 & $\begin{array}{c}37.5 \\
\%\end{array}$ & - & - & 3.06 & .93 & 30.39 & 4 & .000 \\
\hline 7 & $\begin{array}{l}\text { Non-attention to complaints } \\
\text { and observations provided } \\
\text { by customers level service } \\
\text { provided. }\end{array}$ & 1 & $6.2 \%$ & 5 & $\begin{array}{c}31.2 \\
\%\end{array}$ & 6 & $\begin{array}{c}37.5 \\
\%\end{array}$ & 4 & $25 \%$ & - & - & 2.81 & .91 & 32.38 & 3 & .000 \\
\hline 8 & $\begin{array}{l}\text { The number certificates in } \\
\text { the field of applying QS, } \\
\text { which led to confusion in } \\
\text { the selection. }\end{array}$ & 2 & $\begin{array}{c}12.5 \\
\%\end{array}$ & 3 & $\begin{array}{c}18.8 \\
\%\end{array}$ & 2 & $\begin{array}{c}12.5 \\
\%\end{array}$ & 5 & $\begin{array}{c}31.2 \\
\%\end{array}$ & 4 & $\begin{array}{l}25 \\
\%\end{array}$ & 3.37 & 1.40 & 41.54 & 8 & .000 \\
\hline 9 & $\begin{array}{l}\text { Probability of high costs of } \\
\text { applying QMS. }\end{array}$ & 1 & $6.2 \%$ & 3 & $25 \%$ & 6 & $\begin{array}{c}31.2 \\
\%\end{array}$ & 6 & $\begin{array}{c}37.5 \\
\%\end{array}$ & - & - & 3.06 & .93 & 30.39 & 2 & .000 \\
\hline & Total & & & & & & & & & & & 25.48 & 9.39 & 339.67 & & .000 \\
\hline & Total Mean & & & & & & & & & & & 2.83 & 1.04 & & & \\
\hline
\end{tabular}

The values as shown from the results of the previous table (5) regarding the managers' responses about Obstacles facing hotel in application of quality systems , that the total mean (2.83) and the standard deviation is (1.04), less than half the mean, Therefore The data are distributed in a normal distribution and the dispersion rate is acceptable, This also indicates direction results toward is acceptable (H2) There is a relationship between the obstacles facing the hotel in the application quality systems and level of employees performance in food and beverage department in study population hotels.

Q1. It is clear from the data in table (5) the following question that the approval rate was ( Agree \& Strongly Agree ) about boring routine, holding style administrative present and change refusal in hotels, with percentage $56.2 \%$ and the mean was 2.93 , This is consistent with (Carrol and Schneier, 2012) the reactions of employees against desired changes in the organization such as preventing, not having confidence, suspecting, attempts to extend or obstruct the change process are called as resistance against change. This resistance may be at individual, group or organizational level.

Q2. When reviewing the data in the previous table, it was found that the approval rate was( Agree and Strongly Agree ) on Lack of Employee's Participation to Decision 
Makers was percentage $62.6 \%$. The mean was 2.37 and the standard deviation is 1.02 , when commenting on the data received we find that the approval rate is high and may be due to the lack of interest in the sample hotels not to apply the quality of these facilities in the need to raise awareness and education, this result agree with (Ali and Abedalla, 2013) he pointed to Employee trust in management is an important determinant of their willingness to participate in decision making.

Q3. According to the data in table (5) results of the previous question indicate that (Not Agree and strongly Not Agree) about making up arguments for not applying quality concepts with percentage of non-acceptable $43.7 \%$, the mean of 3.12 and the standard deviation is 1.02 is less than half of the mean. According to (Brown and Hepner, 2000) the data are distributed in a natural distribution and the dispersion rate is acceptable and there was a strong moral significance.

Q4. The results indicated that in table (5) approval rate was (Agree and Strongly Agree) about lack of training programs specialized to quality management applications, with percentage $56.3 \%$. The mean was 2.37 and the standard deviation is 0.95 , while the second rank was neutral, $31.2 \%$ due to their lack of the importance of training programs in the field of quality and because they are not interested in applying the quality science from the ground. Therefore they do not care about the specialized training programs in While the latter ranked in the last rank 12.5, they did not agree that the training programs were the reason why the quality was not applied and that they were aware of the importance of the training programs. (Nicula et al, 2014) emphasized the importance of training programs for the employees to the success of any hotel.

Q5. The previous table (5) shows that the total rate of approval for the previous question (Agree and Strongly Agree) on the question no need to apply the quality systems because it is an additional burden in hotels, with percentage $56.3 \%$. The mean was 2.37 and the standard deviation 0.81 was less than half of the mean. The data were distributed and the dispersion rate was acceptable and there was a strong significance. This is confirmed by (Ali and Abedalla, 2013) many companies do not know what quality management is and are afraid of the unknown, afraid that they will have to disclose secret processes and afraid that they will lose their know-how. It goes without saying that we are obliged to maintain confidentiality. They are not aware the importance of quality within the hotel.

Q6. the data in table (5) and following question that results is (Not Agree and Neutral) about not sure to application quality system as required, came in the same ratio $75 \%$ and the mean was 3.06 and the standard deviation is 0.93 , , This is referred to (Sharabi and Davidow, 2010) quality is critical for success. While the economic benefits of quality have been long established, many managers still ignore them at their own risk. This is especially the case for service quality, thus magnifying the potential savings in implementing service quality.

Q7. The following question that the approval rate (Agree and Strongly Agree) that the same results (Neutral) about non-attention to complaints and observations provided by customers at the level of service provided to them, was $37.5 \%$ and the mean was 2.81 and the standard deviation is 0.91 , Where they emphasized the importance of customers complain about level of service quality, This is referred with ( Vivienne and Nerilee ,2010) If business owners take the time to properly measure the revenue lost to customers who left due to poor service and the extra costs involved in re performing.

Q8. showed that the result of question is (Not Agree and Strongly Not Agree) with percentage of disapproval was $56.2 \%$, the mean was 3.37 , and the standard deviation 
was 1.40, By commenting on the data received, William (2009), agree with Acharya and Sanjit (2002) Quality certification should help hotels improve operations, strengthen marketing, and boost staff morale. Hospitality organizations likely will gain operational benefits.

Q9. we find the results is Indicate to (Not Agree) about probability of high costs of applying QMS, that the percentage is $37.5 \%$ and the mean of 3.06 and the standard deviation is 0.93 , that customers have sufficient awareness of the type and level of services provided by the hotel and a good knowledge of the quality of services. This indicated with (Wu et al, 2012). This categorization of quality costs, we look at the ease to quantify measurement costs as well as whether there is an actual quality failure in order to categorize the quality expenses. Prevention costs are very hard to quantify and they are not contingent on quality failure.

\section{Conclusion}

To achieve this objective a systematic approach study was employed to determine the application of quality management principles on the employee's performance in first class hotels in Alexandria, used in the previous literature and suitable to be tested in this study. The findings of this study contributed to both theoretical and managerial perspectives. Quality management principles ISO 9001- 2015 is a systematic quality approach, use of which leads to increase in profitability through improvement employees performance, From the managerial perspective, the results of this study showed that there was a significant relationship between quality management dimensions to improving performance of work in hotel department,

In conclusion, the researcher offers this brief summary of conclusions. This study has advanced research QMP-ISO-9001field by (1) submitting support for using the quality management principles at the individual level of analysis in its entirety improvement of performance of work (2) provide practical results from quality unit in hotels that can be used immediately by practitioners in the real world, and by researchers in a further analysis(3) The interest of the current colleges and institutes of tourism and hotels to renew and update their courses in accordance with the current situation and interest in quality study to graduate cadres academically qualified and able to compete in the labor market(4) develop programs in the field of quality management systems through the introduction of specialized experts in the field of quality to train employees and raise their performance.Moreover, integrating those findings into the model and empirically testing according to quality management principles it would make a further research contribution in this vital research stream.

\section{References}

Acharya, U.H. and Sanjit, R., (2002). "ISO 9000 Certification in Indian Industries": A survey. Total Quality Management. 11 (3): 261-267.

Ahmad Z.A., Yekta Z.A., (2012) "Relationship between perceived organizational support, leadership behavior, and job satisfaction": An empirical study in Iran, Intangible Capital 6 (2): pp521-530.

Ali B.J and Abedalfattah Z., (2013)." The Effect of Quality Management Practices on Organizational Performance in Jordan: An Empirical Study" International Journal of Financial Research, Vol. 4, No. 1: pp 93 - 109.

Al-Otaibi F.M., (2015)" Role of Exploratory Factor Analysis Applicability of TQM Practices on the Items of Quality Culture in the Kingdom of Saudi Arabia, International Journal of Business and Management; Vol. 10, No. 1;pp 136 - 142. 
Brown,G. and Hepner, K., (2000)." The Waiters Handbook", Second Edition, Global Books\& Subscription Services, New Delhi, p7.

Camila,S,F and Mateus,C,G.,(2016)"Analysis of the Relationship Between Management System Standards (ISO 9001, ISO 14001, NBR 16001 and OHSAS 18001) and Corporate Sustainability" Gest. Prod., São Carlos, v. 23, n. 4: p. 689703.

Carroll, S J. and Schneier, C. E., (2012). "Performance Appraisal and Review Systems: The Identification, Measurement and Development of Performance in Organizations". Glenview, IL: Scott, Foremen: pp.154-162.

Deming .W. E., (2008). "Quality Control and Continuous Improvement", Chapter Seven, External Quality Assessments Cambridge, MIT Center for Advanced Engineering Study: pp 97-110.

Dennis Campbell., (2012). "Employee Selection as a Control System", Harvard Business School,: pp97-98.

Derven, M., (2010). "The paradox of performance appraisal".Personnel Journal 69 (2):pp 12-17.

Dudu, O.F. and Agwu, M. E. (2014) "A review of the effect of pricing strategies on the purchase of consumer goods", International Journal of Research in Management, Science \& Technology (E-ISSN: 2321-3264) Vol. 2, No. 2: pp.88102.

Evangelos L., Psomas A., Pantouvakis D. and Kafetzopoulos P.,(2013)" The Impact of ISO 9001 Effectiveness on the Performance of Service Companies", Managing Service Quality: An International Journal, 23(2):pp149- 164.

Flynn, B.B.; Schroeder, R.O.; Sakakibara, S. (2014) "The Impact of Quality Management Practices on Performance and Competitive Advantage". Decis. Sci, 26:pp 659-691.

Fonseca, L. M. (2015). From quality gurus and TQM to ISO 9001:2015: a review of several quality paths. International Journal For Quality Research, 1(9), 167-180.

Hameed. A and Waheed.A, (2011)" Employee Development and Its Effect on Employee Performance A Conceptual Framework" International Journal of Business and Social Science. Centre for Promoting Ideas, USA Vol. 2 No. 13 : pp.224-229.

Hayes, D.K. and Ninemeier, J, D., (2006)." Foundations of Lodging Management" Upper Saddle River, New Jersey: p.150.

International Organization for Standardization (2015). ISO 9001: Quality management systems - Requirements. Genève, Switzerland: International Organization for Standardization: pp. 38-42.

ISO 9001:2015. Quality Management Systems-Requirements. 2015. Available online: https://www.iso.org/ standard/62085.html (accessed on 28 November 2017).

Jaafreh,A.B, (2013) " The Effect of Quality Management Practices on Organizational Performance in Jordan: An Empirical Study", International Journal of Financial Research Vol. 4, No. 1; pp.93:109. www.sciedu.ca/ijfr.

Jackson, S. and Schuller, R., (2012). "Managing Human Resources through Strategic Partnership" (8th ed.). Toronto, Canada: Thompson.

Karapetrovic, S., Willborn, W., (2009). "Integration of Quality and Environmental Management Systems", TQM Magazine, vol. 10, no. 3: pp. 204-213.

King, J.H. and Cichy, R.F., (2012). "Managing for Quality Service in the Hospitality Industry". Pearson Prentice Education, Upper Saddle River, New Jersey. 
Liliane. B, (2016) "MDSAP QMS Continual Improvement (CI) Procedure", Responsible Office/Division, Medical Device Single Program, P: 1-7.

Lin Li., (2010)." Internal Quality Management in Service Organizations: a Theoretical Approach, Business Administration Master's Thesis, Karlstad Business School Handel Karlstad's universities.

Lindebaum D.,(2013) "Cartwright S.A Critical Examination of Relationship between Emotional Intelligence and Transformational Leadership", Journal of Management Studies 47/7: PP.145-161.

Mensah, I., (2009). "Customers' Perception of Food Service Quality: The Case of Cape Coast". Journal of Business and Enterprise Development, 1(1): pp 138-154.

Molina-Azorín, J.F.; Tarí, J.J.; Claver-Cortés, E.; López-Gamero, (2009) "Quality Management, Environmental Management and firm performance: A review of empirical studies and issues of integration. Int. J. Manag. Rev, 11: pp.197-222.

Naseem, A. S and Khusro, P.G., (2011)." Improvement of Hotel Service Quality: An Empirical Research in Pakistan" International Journal of Multidisciplinary Sciences and Engineering, VOL. 2, NO. 5, August: pp.52-56.

Nischithaa, P. \& Narasimha Rao., (2014), "The Importance of Training and Development Programs in Hotel Industry", International Journal of Business and Administration Research Review, 1(5) :pp50-56.

Pantouvakis A. and Kafetzopoulos D., (2013)"The impact of ISO 9001 Effectiveness on the Performance of Service Companies". Managing Service Quality, 23(2), 149-164.

Pastor-Fernández, A., \& Otero-Mateo, M. (2016). "Impact OF Norma ISO 9001:2015 en ambit to engineer: integration en PYMEs. Dyna, 2(91):pp 118-121.

Rampersad, H. K. (2011). "Total Quality Management, an Executive Guide to Continuous Improvement". Berlin - Heidelberg: Springer São Carlos, v. 13, n. 3, pp. 258-270.

Sánchez-Rodríguez, C.; Martínez-Lorente, A.R.(2011)" Effect of IT and quality management on performance". Ind. Manag. data Syst. 111:pp 830-848.

Schroeder, R.G.; Goldstein, S.M.; Rungtusanatham, M.J.(2013)" Operations Management in the Supply Chain: Decisions and Cases"; McGraw-Hill Book Company: New York, NY, USA:pp.241-314.

Sharabi, M and Davidow, M, (2010) " Service Quality Implementation: Problems and Solutions", International Journal of Quality and Service Sciences, Vol. 2 No. 2, 2010. pp. 189-205.

Talib, F. and Rahman, Z. (2010) "Critical success factors of TQM in service organizations: a proposed model”, Service Marketing Quarterly, 31(3): pp.363380 .

Tari, J. J., Molina, J. F., \& Castejon, J. L. (2014). "The Relationship between Quality Management Practices and Their Effects on Quality Outcomes". European Journal of Operational Research, 183(2) :pp 483-501.

Tatiana, Z.G, (2007)." Monitoring of Quality Costs in the Croatian Hotel Industry " Journal of Business \& Industrial Marketing, Pula, Croatia, pp.218-228.

Vivienne McCabe and Nerilee Hing., (2010) "Management for Quality Tourism and Hospitality Services" Study Guide, Southern University, Second edition, pp.4871.

Wellens, Mensah, (2008). "Capacity-Building Needs for National Hydrological Services": World Meteorological Organization Bulletin, v. 57: pp. 152-158. 
William, B. (2009). "Service loyalty. The Effects of Service Quality and the Mediating Role of Customer Satisfaction". European Journal of Marketing, 34(11/12), 1338-1352.

Wu, C.H., Liao, H., Hung, K., \& Ho, Y., (2012). "Service Guarantees in the Hotel Industry: Their Effects on Consumer Risk and Service Quality Perceptions". International Journal of Hospitality Management, 31(3):pp 757-763.

Yeung, A.C.L.; Cheng, T.C. (2005)" Kee-hung, L. An Empirical Model for Managing Quality in the Electronics Industry. Prod. Oper. Manag, 14:pp 189-204.

$\mathrm{Yu}$, 1. (2008). "The Structure and Nature of the International Hospitality Industry". In B. Brother Ton \& r. C. Wood (eds.), Thousand Oaks, CA: Sage Publications, The SAGE handbook of hospitality management ,pp. 62-89. 